[研究ノート]

\author{
グアテマラ共和国地方都市コバン市住民の \\ 食生活と歩行からみた肥満 \\ 富澤優美 ${ }^{* *}$ ・青江誠一郎 $*$ 池上幸江 ${ }^{*}$ \\ (*大妻女子大学， **昭和産業株式会社) \\ (平成25年10月25日受付, 平成26年 3 月 4 日受理)
}

\title{
Obesity assessed from the dietary and walking habits of inhabitants in Coban city of the Republic of Guatemala
}

\author{
Yumi Tomizawa *,**, Seiichiro Aoe *, Sachie Ikegami * \\ * Otsuma Women's University, 12, Sanban-cho, Chiyoda-ku, Tokyo, 102-8357 \\ ** Showa Sangyo Co.Ltd., 2-20-2, Hinode, Funabashi-shi, Chiba, 273-0015 \\ * 102-8357 東京都千代田区三番町12

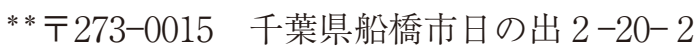

\begin{abstract}
Serious malnutrition has been reported in the Republic of Guatemala, but on the other hand, increases in the number of obese subjects and chronic diseases are found in the urban region. We conducted this study to determine the actual situation and the causes of the obesity in the residents of Coban city located in the central part of this country. During initial survey, the physical characteristics were determined by a one-self-style questionnaire given to the adult inhabitants. In the second survey, we determined the dietary records, physical measurements and the amount of walking by the adult inhabitants.

The obese subjects, who were more than 25 in BMI, were high in the two surveys. The ratio of obese subjects was from $39 \%$ to $46 \%$ in the two surveys. The daily average amount of walking was moderately higher compared to recent Japanese numbers.

However, no significant correlation between the numbers and their BMI was observed. On the other hand, as for the energy and fat intake, there was a weak correlation tendency between the BMI when men and women were put together from the diet survey. No particular serious deficiency was seen in the intakes of vitamins and minerals.

The data presented by the international organizations reveal a serious situation of malnutrition in the Republic of Guatemala. However, in Coban city, obese objects were common. In the Republic of Guatemala, it was shown that the difference is present in the nutrition/health problem by their area. Our results suggest the appropriate nutritional education for these people.
\end{abstract}

\section{1. 緒言}

中南米諸国はそれぞれ政治，経済，社会，民族などの 面での複雑な問題を抱えているが，いずれも今も飢餓や 栄養不良に苦しむ人々が存在する ${ }^{1)}$ 。2007年の国連ミレ ニアムサミット ${ }^{2)}$ では, ミレニアム開発目標として,
2015年までに絶対的貧困人口と飢餓人口の割合を1990年 から半減させることを採択した。国連広報センターによ れば, 飢餓人口などは徐々に低下しているが, 国によっ ては必ずしも改善がみられていない。

$\mathrm{FAO}$ のデータ ${ }^{3)}$ でみる, 中米 (グアテマラ共和国 (以 下，グアテマラ), エルサルバドル，ホンジュラス，二

(40) 40 
カラグア）とパナマの低栄養人口の割合は，グアテマラ 以外では1990-1992年から2003-2005年まではほとんど変 化がないか，低下しているのに対して，グアテマラでは やや増加している。グアテマラの1990年における主要死 亡原因は, 急性下痢症候群, 気管支肺炎, 麻疹, 栄養失 調等であったが, 2001-2003年にはインフルエンザ, 肺炎, 腸の感染症, 周産期に起因した疾患, 不慮の事故, 殺人 が主要な死亡原因となり，1990年代にはみられなかった 脳血管疾患 $(8$ 位), 糖尿病 ( 9 位), 虚血性心疾患 $(10$ 位）などが死因として登場し, 健康問題の推移が示唆さ れている。

グアテマラは中米に位置しているが, 起伏に富んだ地 形であり，人口は1,471万人で，モンゴロイド系マヤ先 住民が38.4\%, 混血・欧州系・アフリカ系の非先住民 61. 6\%とされている。グアテマラはマヤ文明の発祥地で あるが，1523年にスペインの植民地となり，1821年に独 立，中米諸州連合を経て，1838年にグアテマラ共和国が 成立したが，1960年より36年間の内戦が続いた。当初は 非先住民間の権力闘争であったが, 次第に拡大し, 先住 民の大量虐殺，大量の難民を生み出し，多くの村落が消 失した ${ }^{4,5)}$ 。

中米経済統合銀行によれば，グアテマラの経済成長率 は $2 \sim 3 \%$ で継続していたが, 最近はやや向上している。 グアテマラへの経済援助はスペイン，米国が大きく，才 ランダ，スウェーデン，日本なども援助国である。わが 国は当初は無償援助であったが, 現在無償援助協力の対 象国としての適格基準を超えたことで, 国際協力機構 （JICA）を通じた技術協力や借款が中心となっている ${ }^{4,5)}$ 著者の富澤は, かつてグアテマラのコバン市に扔いて 青年海外協力隊員として活動した経験を持っている。そ こでは人々の生活は比較的豊かであり，飢餓は過去の問 題と思われ, 国際的な統計との相違を痛感した。とくに 現地では肥満者が多く, 隊員としての任務終了後もグア テマラの健康問題に関心を持ち， 2 度の訪問を通して食 生活, 体格, 職業, 歩行数などの調査を行った。この結 果は, グアテマラの一地域の問題としてだけではなく, 多くの開発途上国が抱える複雑な健康問題, 食生活の問 題とも関連があると思われる。日本人にとっては, コー ヒーやマヤ文明発祥の地として知られているが, それ以 外ではあまり関心は寄せられていないのが現実である。 しかし，現在多くの開発途上国では貧困にともなう低栄 養が問題となっているが, 同時に比較的経済的に恵まれ ている階層とともに, 貧困層の中にも栄養の過剩やアン バランスに起因する肥満などの問題もみられている ${ }^{6)}$ 。 開発途上国の栄養問題は一層複雑化しているといえよう。

我々は、コバン市に打ける肥満の実態とその原因を明 らかにすることを目的として調査を行った。

\section{2. 方 法}

\section{(1) 調査地域と対象者}

調査はグアテマラ中部のアルタベラパス県コバン市の 住民を対象とした。コバン市は首都のグアテマラ市から バスで 4 時間の距離にある。本調査地域は都市と農村の 中間地域にあたる地方都市である。

対象者は非先住民族を中心とした成人で，アンケート 調査に記入が可能な小学校卒業以上の学歴のものとした。 対象者は富澤がかつて青年海外協力隊員としての活動を 通して知り合った現地の職業訓練学校の教員や学生達の 協力によって紹介された人々である。

調查は 2 回行ったが, 調查用紙作成や対象者への説明 などについては，現地のグアテマラ人のアドバイスと援 助を得た。

なお，コバン市の人口は2002年のデータでは 144,461 人である7)が, 先住民・非先住民別の人口は公表されて いない。コバン市やその周辺はグアテマラの中では先住 民の比率が高い地域であるが，コバン市の都心部には非 先住民が多く，農村部では先住民が多く住んでいる。本 調査の対象者は大部分が都心部に住む非先住民であるが, 厳密な確認は行っていない。

\section{（2）調査方法の概要}

調査は2008年にコバン市住民の状況を把握するために 予備的に行ったものと，2009年に実測を主とする調查の 計 2 回行った。これらはそれぞれ調查 I, 調查IIで示し た。

\section{1）調査 I：体格に関する予備調查}

最初に簡単な調査として, 自己申告に基づいて体格を 調査した。105人の対象者は, 年齢15歳から58歳の男女 であり, 男性 38 人, 女性 67 人であった。調査項目は, 年 齢, 性別, 身長, 体重, 職業である。対象者全員にアン ケートの目的や記入方法について説明した。アンケート 用紙の配布と回収は富澤が直接行った。

\section{2 ) 調查 II：身体計測, 歩行数, 食事に関する調査}

調査 I では自己申告に基づいて肥満の実態を明らかに したが, さらに詳細な調査の必要性を感じた。そこで, 調查 I と同じ条件で被験者 50 人 (男性 20 人, 女性 30 人) に調査協力を依頼した。この調查では, 身体計測, 歩行 数は実測を行った。

身長は卷尺と三角定規を用い，体重はアナログ式体重 計（侏タニタ RAINBOW THA-528-SW）を用いて計測 した。

食事内容は, レンズ付きフィルム(富士フィルム侏 写 るんです Hi-speed1600）を全員に配布して，1日分の食 事と間食すべてを写してもらった。被験者に対しては, カメラの使い方を説明し, さらに説明書も手渡した。カ メラを回収する際に, 調査日の体調や撮影漏れなどの確 認をした。また，食事は普段通りとすることも依頼した。 
なお，撮影の際にはサイズを判断するために，それぞれ にサイズが一定のカードを手渡し，必ず食事と同時に写 すように指示した。

身体活動の指標とした歩行数の調査は, 各被験者に歩 数計（シチズン・システム株) デジタル歩数計 pebTW550）を携帯してもらい, 午前 2 時を起点として 24時間分のデータを集めた。歩数計についても事前に使 い方の説明を口頭で行い, 説明書も配布した。同時に日 常的に運動を行っているか, その内容も含めて聞き取り を行った。

\section{(3) 栄養摂取量の算出}

被験者が写した食事写真と被験者からの聞き取りに基 づいて，栄養摂取量を算出した。グアテマラ固有の料理 については, 3 冊の料理本 ${ }^{8-10)}$ に基づいて, 料理量, 食 材料の重量や配合量を算出した。また, 現地特有の食品 については, キッチンスケール（株）タタデジタルお 料理はかり KD-184）を用いて重量や廃棄量を実測した。 日本でも一般的な料理については, 献立作成時に広く使 用される調理の基礎データと写真から判断できる書物を 参考とした ${ }^{11,12)}$ 。

栄養素算出には地域で一般的に用いられている食品成 分表 ${ }^{13)}$ を用いた。なお, グアテマラでは一般的に砂糖に はビタミン A が強化されており, 米には鉄・ビタミン $\mathrm{B}_{1} \cdot$ ビタミン $\mathrm{B}_{2} \cdot$ ナイアシン・パントテン酸・葉酸が 強化されているので, その数值を用いた。

\section{(4) 統計処理}

図 1 から図 3 では, 相関係数と有意水準を算出した。 表 $1 ， 2$ では, 年齢階層別に平均值と標準偏差で示した。 栄養摂取量を年齢階層別に示すと, 対象者数が少ないた めに個人差が大きく不等分散となる場合があるので, 表 3 では平均值とプールした標準誤差で示した。用いたソ フトウエアは JMP ver9. 02010 (SAS Institute Inc) である。

\section{3. 結果}

\section{（1）調査 I ：コバン市における体格調査（自記式）}

アンケート回答者 105 人の年齢構成とそれぞれの身長, 体重, BMI を表 1 に示した。対象者の職業構成は, 学 生 $30 \%$, 教員・インストラクター・学校職員 $21 \%$, 会社 員 $18 \%$, 家事・無職14\%が主なものであり, 農業従事者 は $3 \%$ となり，その他はそれぞれの比率ではさらに低い。

身長は, 男性では対象者全体の平均值と標準偏差は $169.4 \pm 7.0 \mathrm{~cm}$, 女性では $158.5 \pm 6.0 \mathrm{~cm}$ となった。年 齢階層別にみると，身長では若い人ほど高い傾向があり， 体重は軽い傾向である。その結果, BMI は10歳代, 20 歳代では平均でも24.9以下であるが，40歳代以上では男 女とも25を越えている。全体としてはWHO で適用され ている正常（18.5～24.9）に該当する人が最も多いが, 25を超える人は男性では39\%, 女性では46\%となってい た。

\section{（2）調査II：コバン市住民の身体計測, 食事摂取と歩 行数の関係}

\section{1 ) 身体計測}

調查 I の簡易調査は, アンケート対象者の記述による ものであったが, 調査IIでは，ほぼ同じ条件の対象者に ついて，実測によって身体計測を行った。表 2 にはその 結果を示した。

男性では，身長は年齢階層による差はなかったが，体 重と BMI については調査 I とほぼ同様の傾向であった。 女性では, 調査 I とほぼ同様の傾向がみられた。全体と して, BMI は18.5〜24.9の正常者の割合が最も高かっ たが，BMI25以上の割合は男性では45\%，女性では40\% と高かった。

\section{2 ) 歩行数}

対象者の 1 日の歩行数の分布は表 2 に示した。1 日当 たりの平均歩行数は, 男性では約 11,200 歩, 女性では約 8, 400歩であった。年齢階層別での特性は確認できなかっ た。各階層の対象者数が少なかったことも原因と思われ，

表 1 調査 I のコバン市民調査対象者の特性

\begin{tabular}{|c|c|c|c|c|c|c|}
\hline 性別 & 年齢階層（歳） & 対象者数 (人) & 身長（cm） & 体重（kg） & BMI & 職業など \\
\hline \multirow{5}{*}{ 男性 } & $15 \sim 19$ & 5 & $172.4 \pm 9.4$ & $71.1 \pm 17.2$ & $23.6 \pm 3.4$ & 学生, 会計士 \\
\hline & $20 \sim 29$ & 16 & $171.3 \pm 5.6$ & $67.0 \pm 13.9$ & $22.6 \pm 4.1$ & 学生, 会計士, 教員, インストラクター等 \\
\hline & $30 \sim 39$ & 9 & $163.7 \pm 3.9$ & $70.2 \pm 10.3$ & $26.2 \pm 3.6$ & 技術者, 農業, 大学教員等 \\
\hline & $40 \sim 49$ & 5 & $169.6 \pm 9.8$ & $80.9 \pm 16.8$ & $27.9 \pm 4.4$ & 会社員, 建設業等 \\
\hline & $50 \sim 59$ & 3 & $169.0 \pm 6.6$ & $78.5 \pm 9.1$ & $27.2 \pm 5.2$ & 事務員, 宝石商, 商人 \\
\hline \multirow{5}{*}{ 女性 } & $15 \sim 19$ & 12 & $160.3 \pm 4.3$ & $56.5 \pm 13.3$ & $21.9 \pm 4.5$ & 学生, 事務員, 無職等 \\
\hline & $20 \sim 29$ & 25 & $159.5 \pm 6.3$ & $59.2 \pm 6.2$ & $23.3 \pm 2.4$ & 学生，教員，家事等 \\
\hline & $30 \sim 39$ & 17 & $156.7 \pm 6.9$ & $68.0 \pm 10.5$ & $27.8 \pm 4.3$ & 家事, 秘書, 教員, 商人, 会社員, 美容師等 \\
\hline & $40 \sim 49$ & 8 & $156.6 \pm 6.4$ & $69.8 \pm 12.3$ & $28.7 \pm 6.0$ & 教員，家事等 \\
\hline & $50 \sim 59$ & 5 & $158.2 \pm 4.1$ & $69.1 \pm 10.5$ & $27.6 \pm 3.7$ & 教員, 商人, 薬剂師, インストラクター \\
\hline
\end{tabular}

数值はいずれも平均值と標準偏差で示した。 
表 2 調査IIのコバン市民調査対象者の特性

\begin{tabular}{ccccccr}
\hline 性別 & 年齢階層 (歳) & 対象者数 $(人)$ & 身長 $(\mathrm{cm})$ & 体重 $(\mathrm{kg})$ & $\mathrm{BMI}$ & \multicolumn{1}{c}{ 歩数 } \\
\hline \multirow{4}{*}{ 男性 } & $15 \sim 19$ & 3 & $165.6 \pm 2.4$ & $56.7 \pm 5.0$ & $20.7 \pm 2.2$ & $17,532 \pm 6,749$ \\
& $20 \sim 29$ & 8 & $166.5 \pm 5.8$ & $70.8 \pm 9.4$ & $25.5 \pm 3.5$ & $12,438 \pm 6,253$ \\
& $30 \sim 39$ & 5 & $167.4 \pm 5.1$ & $67.3 \pm 9.4$ & $24.2 \pm 4.4$ & $6,669 \pm 3,188$ \\
& $40 \sim 49$ & 4 & $167.6 \pm 6.7$ & $74.3 \pm 9.3$ & $26.6 \pm 4.3$ & $9,514 \pm 3,497$ \\
\hline \multirow{4}{*}{ 女性 } & $15 \sim 19$ & 5 & $157.9 \pm 5.6$ & $51.4 \pm 6.8$ & $20.7 \pm 3.5$ & $6,588 \pm 3,959$ \\
& $20 \sim 29$ & 8 & $156.2 \pm 5.5$ & $50.6 \pm 6.8$ & $20.8 \pm 3.1$ & $7,238 \pm 3,896$ \\
& $30 \sim 39$ & 10 & $154.7 \pm 7.2$ & $64.1 \pm 10.1$ & $26.9 \pm 4.7$ & $10,898 \pm 3,427$ \\
& 40 以上* & 7 & $154.6 \pm 6.8$ & $67.6 \pm 15.3$ & $28.3 \pm 6.3$ & $7,573 \pm 5,638$ \\
\hline
\end{tabular}

数值はいずれも平均值と標準偏差で示した。

*58歳，66歳女性各 1 人を含む。

表 3 調査 II のバン市民調査対象者の栄養摂取量

\begin{tabular}{|c|c|c|c|c|c|c|c|c|c|c|c|c|}
\hline 性別 & $\begin{array}{c}\text { 年齢階層 } \\
\text { (歳) }\end{array}$ & $\begin{array}{l}\text { 人数 } \\
\text { (人) }\end{array}$ & $\begin{array}{c}\text { エネルギー } \\
\quad(\mathrm{kcal})\end{array}$ & $\begin{array}{c}\text { たんぱく質 } \\
(\mathrm{g})\end{array}$ & $\begin{array}{c}\text { 脂 質 } \\
(\mathrm{g})\end{array}$ & $\begin{array}{c}\text { 炭水化物 } \\
(\mathrm{g})\end{array}$ & $\begin{array}{c}\text { ビタミン } \mathrm{B}_{1} \\
(\mathrm{mg})\end{array}$ & $\begin{array}{c}\text { ビタミン } \mathrm{B}_{2} \\
(\mathrm{mg})\end{array}$ & $\begin{array}{c}\text { ビタミン C } \\
(\mathrm{mg})\end{array}$ & $\begin{array}{c}\text { ビタミン A } \\
(\text { (レチノール } \mu \mathrm{g})\end{array}$ & $\begin{array}{c}\text { カルシウム } \\
(\mathrm{mg})\end{array}$ & $\begin{array}{l}\text { 鉄 } \\
(\mathrm{mg})\end{array}$ \\
\hline \multirow{5}{*}{ 男性 } & $15 \sim 19$ & 2 & 1,959 & 59.5 & 55.3 & 316 & 1.32 & 10.35 & 40.8 & 452 & 748 & 13.8 \\
\hline & $20 \sim 29$ & 8 & 2,262 & 86.4 & 71.2 & 325 & 1.53 & 4. 30 & 58.8 & 702 & 755 & 19.9 \\
\hline & $30 \sim 39$ & 5 & 2,340 & 78.8 & 75.5 & 336 & 1.75 & 1.77 & 54.1 & 715 & 687 & 25.2 \\
\hline & $40 \sim 49$ & 4 & 2,425 & 97.9 & 69.9 & 358 & 1.33 & 1.56 & 40.8 & 522 & 862 & 17.5 \\
\hline & $\begin{array}{c}\text { pooled } \\
\text { SE }\end{array}$ & & 103 & 6.0 & 4.3 & 16 & 0.14 & 1. 31 & 10.1 & 59 & 57 & 1.8 \\
\hline \multirow{5}{*}{ 女性 } & $15 \sim 19$ & 3 & 2,018 & 76.9 & 77.5 & 258 & 1.60 & 2. 01 & 85.5 & 969 & 546 & 20.7 \\
\hline & $20 \sim 29$ & 7 & 1,806 & 63,2 & 65.4 & 247 & 1. 45 & 1.72 & 60.8 & 710 & 510 & 14. 2 \\
\hline & $30 \sim 39$ & 8 & 2,035 & 80.6 & 64.0 & 289 & 1.82 & 3. 72 & 59.2 & 776 & 668 & 14.6 \\
\hline & $40 \sim 49$ & 5 & 2,241 & 71.6 & 84.2 & 305 & 1.35 & 5. 21 & 92.9 & 1,005 & 620 & 16.3 \\
\hline & $\begin{array}{l}\text { pooled } \\
\text { SE }\end{array}$ & & 70 & 4.0 & 3. 6 & 12 & 0.14 & 0.93 & 9.5 & 82 & 46 & 1.0 \\
\hline
\end{tabular}

数值は平均值を示し，全体の標準誤差として男女別に pooled SE を示した。

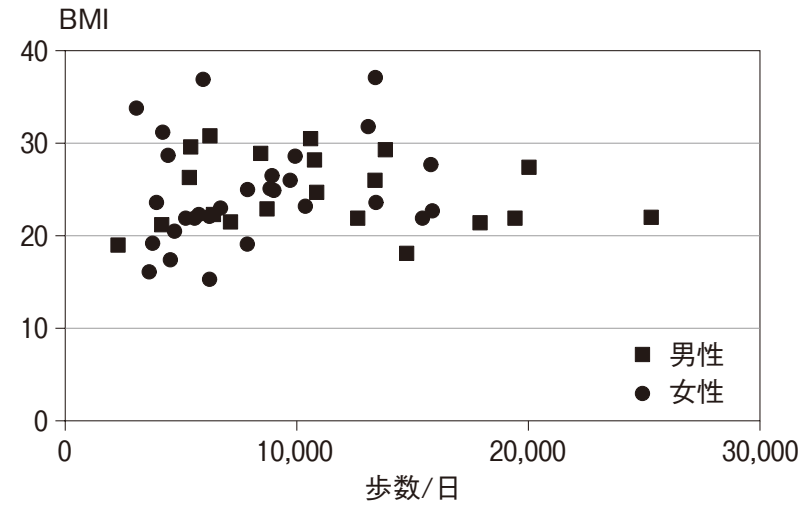

図 1 調査 II のコバン市民調査対象者の 1 日の歩数と B M |の相関

$r=0.15, p=0.30$

今後の詳細な調査が必要である。

図 1 には, 歩行数と BMI の相関を示した。両者の間 には男女いずれも，また男女をプールしても有意な相関 はみられなかった。グアテマラではとくに歩行数に対す る推奨值はないが，日本における「健康日本21」の男性 9, 200歩，女性8, 300歩を基準とすると，男性では57\%， 女性では $42 \%$ の対象者がこれを越えていた。

\section{3 ）食事調査}

食事を記録したカメラは被験者からすべて回収された
が，写真撮影に失敗したもの，記録忘れ，体調不良で食 事を抜いたものなど，記録が不適切なものを除いて41人 （男性 19 人，女性 22 人）加，食品の摂取頻度，栄養摂 取量を算出した。

表 3 には，被験者のエネルギー，たんぱく質，脂質， 炭水化物, ビタミン, ミネラルの摂取量を, 男女別, 年 齢階層別に示した。表 4 には, Instituto de Nutrición de Centro América y Panamá (INCAP) ${ }^{14)}$ の推奨量の例とし て，日常の生活活動が軽度と中等度の場合を示した。

男性では，エネルギー摂取量は生活活動が軽度と中等 度のいずれの推奨量に比べても低いが，たんぱく質や脂 質は推奨量に近く，炭水化物の摂取量はかなり低い。他 方，女性では，エネルギーは生活活動が中等度の場合の 推奨量に近く，たんぱく質は20歳代以外では生活活動が 軽度, 中等度の推奨量より高い傾向にあり, 脂質はいず れの生活活動度の推奨量より高く, 炭水化物は低い。男 女とも極端なエネルギー不足はみられなかった。

年齢階層別に栄養摂取量をみると，一部例外はあるが， 男女ともに年齢が上がるにつれてエネルギー，炭水化物 の摂取量が増加する傾向がみられた。たんぱく質と脂質 の摂取量では年齢階層との関係は明確ではなかった。

図 2 には, エネルギー摂取量と BMI の関係を示した。 男女別では有意な相関はみられなかったが，男女をプー 
表 4 INCAP の栄養推奨量

\begin{tabular}{|c|c|c|c|c|c|c|c|c|c|c|c|}
\hline 性別 & $\begin{array}{c}\text { 生活 } \\
\text { 活動度 }\end{array}$ & $\begin{array}{c}\text { エネルギー } \\
\quad(\mathrm{kcal})\end{array}$ & $\begin{array}{c}\text { たんぱく質 } \\
(\mathrm{g}) \\
(10 \sim 14 \%)^{* 1}\end{array}$ & $\begin{array}{c}\text { 脂 質 } \\
(\mathrm{g}) \\
(20 \sim 25 \%)^{* 1}\end{array}$ & $\begin{array}{c}\text { 炭水化物 } \\
(\mathrm{g}) \\
(60 \sim 70 \%)^{* 1}\end{array}$ & $\begin{array}{c}\text { ビタミン } \mathrm{B}_{1} \\
(\mathrm{mg})\end{array}$ & $\begin{array}{c}\text { ビタミン } \mathrm{B}_{2} \\
(\mathrm{mg})\end{array}$ & $\begin{array}{c}\text { ビタミン C } \\
(\mathrm{mg})\end{array}$ & $\begin{array}{c}\text { ビタミン A } \\
(\text { レチノール } \\
\mu g)\end{array}$ & $\begin{array}{c}\text { カルシウム } \\
(\mathrm{mg})\end{array}$ & $\begin{array}{l}\text { 鉄 } \\
(\mathrm{mg})\end{array}$ \\
\hline 男性 & $\begin{array}{l}\text { 軽 } \\
\text { 中 }\end{array}$ & $\begin{array}{l}2,600 \\
3,100\end{array}$ & $\begin{array}{c}66 \sim 93 \\
78 \sim 109\end{array}$ & $\begin{array}{l}59 \sim 74 \\
69 \sim 86\end{array}$ & $\begin{array}{l}398 \sim 464 \\
465 \sim 543\end{array}$ & 1.2 & 1.3 & 60 & 600 & 800 & $8^{* 2}, 19^{* 3}$ \\
\hline 女性 & $\begin{array}{l}\text { 軽 } \\
\text { 中 }\end{array}$ & $\begin{array}{l}1,950 \\
2,100\end{array}$ & $\begin{array}{l}49 \sim 68 \\
53 \sim 74\end{array}$ & $\begin{array}{l}43 \sim 54 \\
47 \sim 58\end{array}$ & $\begin{array}{l}293 \sim 341 \\
315 \sim 368\end{array}$ & 0.8 & 1.1 & 60 & 500 & 800 & $16^{* 2}, 24^{* 3}$ \\
\hline
\end{tabular}

INCAP : Instituto de Nutrición de Centro América y Panamá

*1 : エネルギーに対する比率

*2: 動物性食品由来

*3: 植物性食品由来

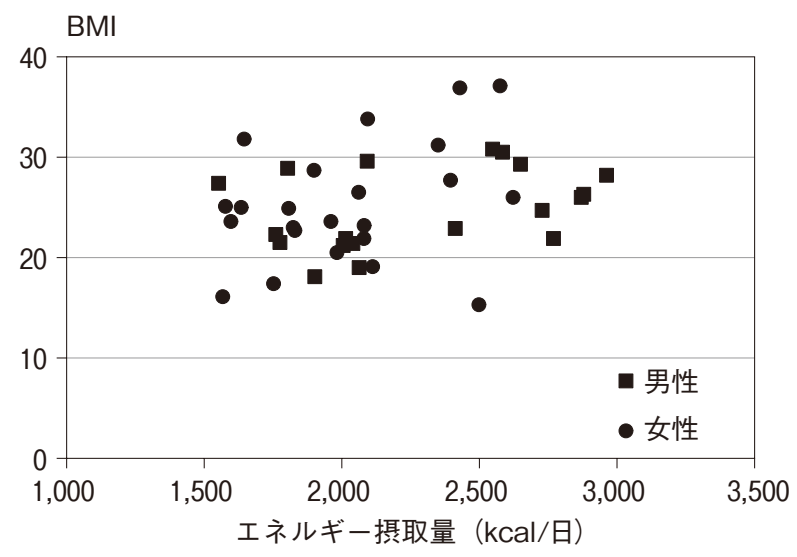

図 2 調査IIコバン市民調査対象者のエネルギー摂取量と $\mathrm{BMI}$ の相関

$r=0.29, \quad p=0.06$

ルすると，相関傾向がみられた $(p=0.064) 。$

また，図 3 には脂質摂取量と BMI の関係を示したが, 男女別では有意な相関はみられなかった。男女をプール すると，相関傾向がみられた $(p=0.060)$ 。

一般的に開発途上国では，ビタミン $\mathrm{A}$ や鉄などの不 足が問題となっている。コバン市の対象者ではこの不足 は顕著ではない。すでに述べたように，グアテマラでは ビタミン類やミネラル類の強化食品が利用されて㧍り, 栄養摂取量はこれを前提として計算した。カルシウムは 男女ともやや不足気味であるが，日本人の摂取レベルよ りは高い。他方ビタミンでは, ビタミン $\mathrm{B}_{1}$ や $\mathrm{B}_{2}$ では推 奖量を充足しており, ビタミン Cについてもほぼ充足 している。ビタミン A では男性の 20 歳代や 40 歳代で不 足がみられるものの, その他の年代や女性では推奨量を 充足していた。微量栄養素の摂取量と年齢階層との関係 は明確ではなかった。

なお，微量栄養素のうち, ビタミン $\mathrm{B}_{2}$ とビタミン $\mathrm{C}$ では個人差が大きく，不等分散であったが，他の微量栄 養素では等分散であった。ビタミン $\mathrm{B}_{2}$ では, グアテマ ラ特有の食品であるタマルに極端に含有量が高く，その 摂取の有無がビタミン $\mathrm{B}_{2}$ 摂取量に大きく影響している。 他方, ビタミン C は野菜や果物の摂取量の差が大きく 影響しているものと推測される。

表 5 には，主要な栄養素の給源となっている食品を示

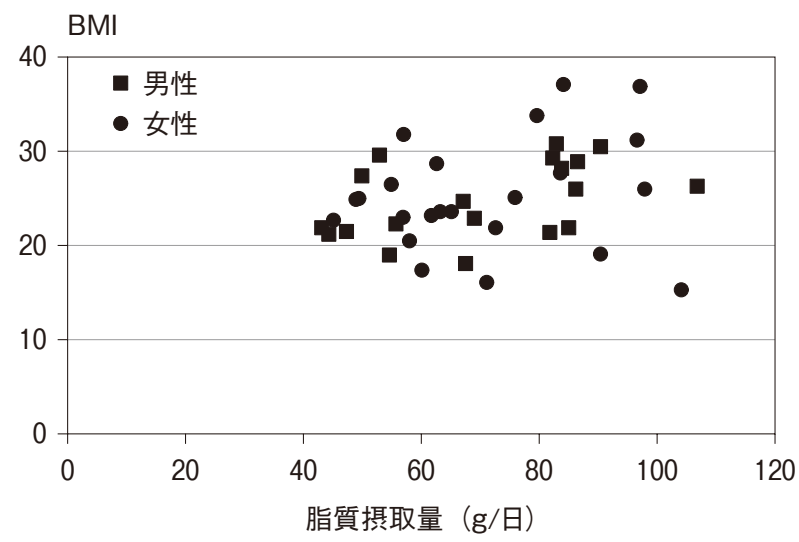

図 3 調查 II のコバン市民調查対象者の脂質摂取量と $\mathrm{BMI}$ の相関

$r=0.29, \quad p=0.06$

した。脂質は，油脂からの摂取の寄与が高い。グアテマ ラでは, 卵料理に植物性, 動物性の油脂を多く使ってい る。牛肉や鶏肉料理からの脂肪摂取も多い。たんぱく質 源として寄与率の高い食品は鶏肉であり, 肉類としては よく利用されている。トルティージャはグアテマラに固 有のとうもろこしを材料とする食品であるが，炭水化物 源として最も寄与率が高い。また, グアテマラではイン ゲンマメを餡状に調理したり，調理すみの缶詰を利用し て頻繁に食べられて打り，鉄・マグネシウム・亜鉛・カ リウム・葉酸などのミネラルやビタミンの給源となって いる。現在, 砂糖にはビ夕ミン A が強化され, 強化米 は鉄・亜鉛・マグネシウム・ビタミン $\mathrm{B}_{1}$ ・葉酸などへ の寄与率が高い。

\section{4. 考察}

グアテマラで低栄養が最も深刻と思われる地域は，都 市から遠く離れた北部，北西部の山間部である。これら の地域には先住民族が多く住み，ほとんど自給自足の生 活をしているといわれている。彼らはトウモロコシとイ ンゲンマメを主たる食料として扔り, グアテマラの中で も最貧困層である。これらの地域に打ける栄養・健康問 題に関する詳細な調查はほとんど行われていない。長い 内戦の影響が強く, これらの地域に入ることも極めて困 難な状況である。 
グアテマラ共和国地方都市コバン市住民の食生活と歩行からみた肥満

表 5 調査 II のコバン市民調査対象者の栄養摂取給源食品

\begin{tabular}{|c|c|c|c|c|c|}
\hline \multirow{2}{*}{ 栄養素 } & \multicolumn{5}{|c|}{ 寄与率の高い食品（上位 5 位まで） } \\
\hline & 1 位 & 2 位 & 3 位 & 4 位 & 5 位 \\
\hline たんぱく質 & 鶏肉 & トルティージャ & 卵 & 牛肉 & インゲンマメ \\
\hline 脂質 & 油脂 & 牛肉 & 鶏肉 & 生クリーム & アボカド \\
\hline 炭水化物 & トルティージャ & 強化米 & パン & 強化砂糖 & インゲンマメ \\
\hline ビタミン $\mathrm{B}_{1}$ & 強化米 & トルティージャ & インゲンマメ & パン & コーンフレーク \\
\hline ビタミン $\mathrm{B}_{2}$ & タマル* & 卵 & コーヒー & パン & コーンフレーク \\
\hline ビタミン C & ブロッコリー & キャベツ & トマト & オレンジジュース & ピーマン \\
\hline ビタミン A & 強化砂糖 & 卵 & にんじん & 生クリーム & コーンフレーク \\
\hline カルシウム & トルティージャ & 牛乳 & インゲンマメ & パン & パンケーキ \\
\hline 鉄 & インゲンマメ & パン & 強化米 & コーンフレーク & 卵 \\
\hline
\end{tabular}

中米地域に関する国連開発計画による人間開発報告 書 ${ }^{15)}$ におけるジニ係数や人間開発指数, ユニセフの世界 子供白書 ${ }^{16)}$ における低栄養人口の推移, 新生児死亡率, 乳児死亡率， 5 歳未満児死亡率などからみて，グアテマ ラの状況は中米諸国の中で最も深刻である。恐らく，先 住民族を中心とした最貧困層への適切な援助が行き届い ていない結果と思われる。

他方，筆者の富澤が海外青年協力隊員として滞在した コバン市都市部のように非先住民が比較的多く住む地域 では，栄養状態はかなり改善されており，むしろ肥満者 が目立つ状況になっている。グアテマラにおける主要な 死亡原因は，1990年では低栄養に起因する特徴を持って いたものが，2001年から2003年ではそれらに加えて脳血 管疾患などの慢性疾患による死亡率が増加している ${ }^{3)}$ 。 開発途上国では，低栄養と過栄養が混在することが指摘 されているが，まさにグアテマラでもその状況は同様で あると思われる。グアテマラにおける肥満者の割合に関 する WHO の報告 ${ }^{6)}$ では，BMI が25以上は男性では $57.0 \%$ ，女性では65.4\%, BMI が30以上ではそれぞれ $15.7 \%$ と $29.7 \%$ である1998年に発表された中南米諸国 に関する論文 17 でも，すでに肥満者の増加が指摘され， グアテマラだけの問題ではない。すなわち，ラテンアメ リカやカリブ諸国では国によって傾向は異なるものの, 1980年代半ばより肥満者が増え始めている。

本研究は開発途上国として位置づけられているグアテ マラにおける栄養のアンバランスがもたらす問題の背景 を明らかにして，今後の現地における活動に生かしたい と考えて行ったものである。グアテマラの非先住民を対 象とする研究はINCAP と米国の大学の共同によって, グアテマラ東部エルブロクレッソ県の 4 村について継続 して行われている ${ }^{18)}$ 。2002年の報告では，これらの村の 住民のうち，主にグアテマラ市に移住したものは，体脂 肪率が高く，血中コレステロールなども高い。さらにこ れより 5 年後の報告 ${ }^{19)}$ では，男性において代謝性疾患や
心筋梗塞の罹患率は, 非農業従事者のほうが農業従事者 より有意に高くなることを示した。この報告では，男性 においては身体活動量の差異が要因であると推測してい る。また，女性については都市生活者のほうが代謝性疾 患や心筋梗塞の罹患率が高くなっている。

今回我々が調査対象としたコバン市については，これ までとくに報告はない。また，現地においても栄養調査 などは行われていない。本調査では，まず予備的な調査

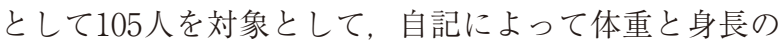
調査を行った。その結果，BMI25以上は16〜56歳の男性 では39\%，15～58歳の女性では46\%であった。また，年 代が上がるにつれて BMI は高くなる傾向があり，とく に40歳代で顕著であった。このデータは WHO の報告に 比べるとやや低いものの, 傾向は類似している。日本の 2011年の国民健康・栄養調査 ${ }^{20)}$ では，20歳以上の成人に おける BMI 25 以上は男性では30.5\%，女性では $20.8 \%$ である。このようなわが国の状況と比較してもコバン市 の肥満の実態は深刻であることがうかがえる。

その背景としては，食生活と日常の身体活動量が推察 される。職業との関係から日常の身体活動量との関係を 解明しようとしたが，アンケート回答者は大部分が学生, 教員，会社員であり，女性では主婦が多く，身体活動量 が多いと推測される農業従事者はほとんどいなかったた め，明らかにできなかった。

そこで，第 2 回の調査IIで，実測による身体計測と 歩行調査, 写真撮影による食事調査を行った。身体計測 では予備調査とほぼ同様の結果であった。食事調査の結 果からは，エネルギー摂取量は男性では生活活動度が軽 度の INCAP の推奨量より低いが，女性では生活活動度 の中等度に近く, いくつかの調査から女性の肥満率の高 いことと関連がみられた。また，男性では脂質摂取量が INCAP の推奨量に近いが, 女性では高く, 女性の肥満 の原因として考えられる。年齢階層別にみると, 男女と もに年齢が上がるにつれてエネルギー摂取量が増加する 
傾向にあり, 肥満者増加の原因と考えられる。これらの 結果から, INCAP の推奨量が現状のコバン市民に適切 かの検討が必要と思われる。

コバン市における食生活は伝統的なグアテマラ料理が 残っており，とくにインゲンマメは先住民のみならず, 非先住民の間でも現在もかなり摂取されている。インゲ ンマメは微量栄養素の給源として重要である。

歩行調査から，日常の身体活動量を測定したが，日本 人の平均的な歩行数に比べてやや高い。しかし, 恐らく 従来のグアテマラ人の身体活動量に比べると低下してい るのであろう。かつては農業従事者が多かったが, 最近 では会社員など事務的な仕事に従事するものが多くなり また日常生活においても車や公共交通の利用，家庭内に おける電化製品の増加が, 身体活動量の低下の原因と なっていると推測される。

INCAP と米国の大学との共同研究 21$)$ では, グアテマ ラにおける肥満者の増加の要因として, 胎児期・幼児期 の低栄養から，急速な食生活の変化を挙げている。この 論文では，1969１977年の胎児・幼児の調査を基に， 1988～1989年， 1991～1994年に成長後の体重と比較して いる。このうち，農村地域から都市に移住したものでは とくに肥満が顕著である。

グアテマラの比較的経済状態が恵まれている人々につ いては, 肥満が一般化していると推測される。今回の調 査では，肥満者増加の原因について十分には解明できな かったが, 恐らく多様な要因の複合的な結果と考えられ る。この実態とその要因については，詳細にまた広範な 調査が求められるが, 貧しい胎児期・幼児期からの食生 活の急速な変化が肥満を一層深刻にしている可能性もあ る。他方, 肥満になりやすい遺伝要因についても検討が 必要であろう。

今回の調査は, 調査担当者の滞在期間, 測定機器, 研 究協力者の確保などが困難な中で行わざるをえなかった。 そのために調査対象者数が十分ではなく，また観測日数 が1日であり，文字等が理解できるなどの条件が必要で あるために調査対象者に偏りがあり，さらに対象者らは 調査に不慣れであるなど，調査データが実態を十分に反 映していないことが考えられる。しかし, 開発途上国と してはわが国には馴染みの少ない国であるが, ボラン ティア活動に加わる人もいるため，それらの人々の参考 になるのではないかと考える。また，いずれにしても食 事や身体活動の重要性についての住民への啓発活動が緊 急の課題であり，この面でわが国の栄養学や栄養指導に 係る知識や経験がグアテマラの人々の健康増進に生かさ れることが望まれる。

\section{5. 結論}

グアテマラ共和国は, 中米 5 か国の中では生活関連指 標や健康状態に関する指標が最も深刻な状況にある。長 い内戦を経験しており，とりわけ先住民と非先住民の格
差がこれらの指標に影響している。グアテマラ中部のコ バン市の主に非先住民成人を対象として, 予備調査と実 測に基づく調査を行った。その結果は, 以下のとおりで ある。

1. BMI25以上の肥満傾向者や肥満者の比率は中高年齢 層において高く，とくに女性で顕著であった。

2. 日常の歩数は平均で 9,600 歩位であり, 日本人の平 均歩数より高いものの, 日常の身体活動の低下が推測 された。

3. グアテマラの伝統的な食事としてインゲンマメやト ルティージャは現在も高い比率で食べられているが, とくに中高年齢層でエネルギー摂取量が高く, BMI とエネルギーと脂質摂取量に相関がみられ，肥満の要 因となっていると思われる。

4.コバン市では，栄養調査や栄養指導などの活動はほ とんど行われていない。肥満者の高比率からみて，実 態の把握と一般市民への啓発活動が必要であることが 示された。

\section{謝 辞}

本調査は, Kyra Fernandez 氏, Dafne Fernandez 氏, Isorina Garcla 氏, Lucrecia Barrios 氏を始め, コバン市 の多くの方々に大きな協力を賜りました。深く御礼を申 し上げます。また本研究の遂行にあたり，ご指導を賜り ました大妻女子大学 小林実夏准教授に深く御礼を申し 上げます。

\section{文献}

1）外務省：グアテマラ共和国, http://www.mofa.go.jp/ mofaj/area/latinamerica.html

2）国連ミレニアム開発目標報告：目標(1); 極度の貧困と 飢餓の撲滅, p. 6-13, http://www.unic.or.jp/files/MDG_ Report_2013_JP.pdf

3 ) FAO : Panorama del hambre en América Latina y Caribe 2008, http://www.bvsde.paho.org/texcom/nutricion/panorama. pdf

4) 狐崎知巳 : 先住民族と貧困, 市民の安全保障/桜井三枝 子編：グアテマラを知るための 65 章, 明石書店, 東京, p.153 -161 (2006)

5 ）中原篤史：僻地農村とドナーの援助／桜井三枝子編：グ アテマラを知るための65章, 明石書店, 東京, p.162-165 (2006)

6 ) WHO Global Infobase:Stop the Global Epidemic of Chronic Disease, www.who.int/infobase

7 ) XI Censo Nacional de Problación y VI de Habitación, 2002, http://wikiguate.com.gt/wiki/cobán

8 ) Ortiz de Lopez, J., de Mendez, C., Lopez, L.: Cocina Guatemala Recetas Típicas, Editorial Artemis Edinter, Guatemala, p.24-119 (2007)

9) Balsells de Agruilar, Y::Cocina Guatemaltea Arte, sabor y colorido, Editorial Piedra Santa, Guatemala, p.1-131 (2003)

10) Franco de Alvarez, A.S.:Cocina Regional Guatemalteca, Editorial Piedra Santa, Guatemala, p.25-297 (2003) 
11）「栄養と料理」家庭料理研究グループ編：調理のための ベーシックデータ, 女子栄養大学出版部, 東京, p.12-32, p.60 -87, p.144-145 (1993)

12）香川綾編：食品80キロカロリーガイドブック，女子栄養 大学出版部, 東京, p.16-131（1993）

13) INSTITUTO DE NUTRICION DE CENTRO AMERICA Y PANAMA (INCAP): Tabla de Composicion de Alimentos de Centroamerica, Segunda Edicion, Guatemala, p.17-74（2007）

14) Torun, B., Menchu, N.T., Elias, L.G.: RECOMENDACIONES DIETETICAS DIARIAS DEL INCAP Edicion 45 Aniversari, Guatemala, abril (1996)

15）国連開発計画：人間開発報告書2011 持続可能性と公平 性一より良い未来をすべての人に一, http://www.undp.or. jp/hdr/global/pdf/111102HDR2011_final3.pdf

16） ユニセフ：世界子供白書2007, http://www.unicef.or.jp/ library/pdf/haku2007. pdf
17) Martorell, R., Khan, L.K., Hughes, M.L., Grummer-Strawn, L.M.: Obesity in Latin American women and children, J. Nutr., 128, 1464-1473 (1998)

18) Torum,B., Stein, A.D., Schroeder, D., et.al.: Rural-tourbam migration and cardiovascular disease risk factors in young Guatemalan adults, Inter. J. Epidemiol., 31, 218-226 (2002)

19) Gregory, C.O., Dai, J., Ramirez-Zea, M., Stein, A.D.: Occupation is more important than rural urbanresidence in explaining the prevalence metabolic and cardiovascular disease risk Guatemalan adults, J. Nutr., 137, 1314-1319 (2007)

20）厚生労働省：平成23年国民健康・栄養調査の概要, p. 9 , http://www.mhlw.go.jp/stf/houdou/2r9852000002q1wo.pdf

21) Schroeder, D. G., Martorell, R.,Flores, R.Infant and child growth and fatness and fat distribution in Guatemalan, Am. J. Epidemiol., 149, 177-185 (1999) 